\title{
Lenin as a development economist: A study in application of Marx's theory in Russia
}

\author{
Denis V. Melnik* \\ HSE University, Moscow, Russia
}

\begin{abstract}
The paper provides an interpretation of Lenin's earliest contributions (made in 1893-1899) to the study of economic development. In the 1890s, Lenin joined young Marxist intellectuals in their fight against the Narodnik economists, who represented the approach prevalent among the Russian radical intelligentsia in the $1870 \mathrm{~s}-1880 \mathrm{~s}$. That was the fight over the right to control the Marxist narrative in Russia. Lenin elaborated his theoretical interpretation of Marxism as applied to the contentious issues of Russia's economic development. The paper outlines the context of Lenin's activity in the 1890s. It suggests that the main theoretical challenge to "orthodox Marxist" intellectuals in applying Marx's theory to Russia stemmed not from their designated opponents, but from Marx himself, who presented two divergent scenarios - the dynamic and the breakdown - for capitalist development. Lenin provided an analytical substantiation for the dynamic one but eventually allowed for consideration of structural heterogeneity in the development process. This resulted in the notion of unevenness, on which he would rely upon later, in his studies of imperialism. The paper also briefly considers the place of Lenin's early development studies in his legacy.
\end{abstract}

Keywords: Lenin, Marxism, Marxism in Russia, theories of economic development, Marxist theory of accumulation.

JEL classification: B14, B24, B31.

\section{Introduction}

The amount of literature dedicated to Lenin is vast. The critical review of that literature would require an extensive study of its own. The history of Lenin studies, both in the Soviet world and outside it, made his activities some of the most documented among historical actors of his time. Yet that history tells more about the political trends of the twentieth century than about Lenin himself. The author of one recent study distinguished "three Lenins": "the living Lenin, who created Bolshevism,

\footnotetext{
* E-mail address: dmelnik@hse.ru
} 
led the Bolsheviks to victory in 1917"; the posthumous Lenin as Stalin fashioned him"; Lenin as perceived by the perestroika reformers: "a Marxist idealist, an antiStalinist and fundamentally a democrat." "Both posthumous figures were carved out of the original; both had some claim to represent him; neither fully captured him" (Gooding, 2002, p. vii). This list of "Lenins" is by no means exhaustive. But the main challenge has always been posed by "the living Lenin," made elusive by the accumulated amount of conflicting interpretations, each claiming to convey "the original."

All Lenin's activities were usually scrutinized in terms of his actions as the leader of Bolshevism, and evaluated in terms of the trajectory (real, potential, or desired) of the history of Soviet Russia. As a result, Lenin, the towering figure of the political history of the past century, has supplanted Lenin the intellectual. Lenin is somewhat lost to intellectual history (and perhaps the Soviet hagiography contributed to this at least as much as anti-Bolshevik studies). In general, the widespread approach crossing partisan lines assumed that Lenin was a great politician, but not a theorist.

Arguably, the enormous attention paid to Lenin's intellectual legacy in the twentieth century arose from different strands within Marxism. After the crucial period of 1956-1968, those can be boiled down to the confrontation between the Soviet and anti-Soviet approaches. ${ }^{1}$ An essential point of that confrontation can be encapsulated in the question: How much Marx was there in Lenin? One author indicated in the 1970s that Soviet historiography acknowledged the impact of the Russian revolutionary tradition, but "the prevailing interpretation holds that Lenin's political ideas were mainly inspired by Marx." On the contrary, Western authors tended to emphasize the influence of Russian radicalism (Theen, 1973, p. 72). The same author holds that "Bolshevism [...] is best understood as an amalgamation of the economic and historical materialism of the Marxist doctrine and the voluntarism of the Russian revolutionary tradition, as expressed in Lenin's personality" (Theen, 1973, p. 71). Thus the intellectually sophisticated evolution of Marxism in Western social democracy was contraposed to the reflections of Western ideas in wellintentioned but erratic movements of a (or, perhaps, the) Russian soul.

In recent decades, the shift in attention away from the political context of the twentieth century, the departure from the ideological framework of the Cold War, and the weakening of the premises of the Eurocentric approach have made it possible to loosen the grip of East-West dualism in Lenin studies. "Though Lenin did not begin his revolutionary career as a Marxist, this does not mean that his Marxism was perfunctory, that it was mere gloss on a pursuit of power by any means. Once converted, Lenin never questioned the basic principles of Marxism as he had originally understood them. [...] Marxism was the rock on which he founded his life - without it there could have been no Leninism" (Gooding, 2002, p. 34). It is admitted that Lenin's political project "was driven by a highly optimistic, indeed romantic, scenario of inspiring class leadership that had strong roots in European Social Democracy" (Lih, 2011, p. 16).

Still, the issue of Lenin's consistency as a Marxist theorist remains. The reception of Marxism in Russia (as economics and not as a philosophy of history) required the interpretation if only because Russia was a relatively backward economy, while

\footnotetext{
"Anti-Soviet" does not necessarily stand for anti-Communist. Lenin, the reformer and architect of NEP outlined above as "Lenin number three," usually got positive acclaim in accounts opposite to the "actually existing socialism," both in and outside of the Soviet world, being considered as the alternative to Stalin. See, e.g., Lewin (1968/2005).
} 
Marx's theory assumed the situation of a fully developed capitalist mode of production. Lenin embraced the message of the inevitability of capitalist development in Russia and elsewhere, and staunchly defended it from attempts to outline some particular "Russian road" to development (Wada, 1983). The question for Lenin was never whether the peculiar institutions of backwardness could prevent the expansion of capitalism "by the book": he got the firm (dogmatic or otherwise) grasp of Marxism to assume the superstructure may change the basis. The question was how to apply the principles of the political economy of the developed economic system to a developing one (Milios, 1999). The paper presents an interpretation of this endeavor of Lenin's at the early stage of his intellectual development.

\section{Lenin's early development studies in context}

The radicalization of young Vladimir Ulyanov presumably began in 1887, when he was 17, following the trial and hanging of his older brother, Alexander, who had been involved in a plot to kill Russian tsar Alexander III. In August of the same year Lenin began law studies at the Kazan University only to be excluded and sent in exile to the family estate in the Kazan region due to his participation in that December's student unrest. There he spent almost a year digging into the literature available at the home library, mostly Russian journals of the 1860 s- 1880 s. It was in this period that he might have encountered the tradition of Russian radicalism as expressed with "the Aesopian language" in censored publications.

"In October 1888 restrictions were loosened enough to allow Vladimir and his family to move back to Kazan. Here the properly Marxist stage of Vladimir's evolution began, as he participated in illegal Social Democratic reading circles and began to cut his teeth on Marx's Capital. Here began the love affair with the writings of Marx and Engels that continued all his life" (Lih, 2011, p. 33). By that time, it should be noted, not only the first but also the second volume of Capital had been available in Russian (Russian editions appeared in 1872 and 1885 respectively), though Lenin might have used German editions as well. Characteristically, his first analytical intervention regarding Marx's theory (Lenin, 1893b/1977) ${ }^{2}$ was focused on the elaboration of Marx's reproduction schemes from the ch. XXI of the $2^{\text {nd }}$ volume of Capital. ${ }^{3}$ In December 1894, in a letter to his sister Maria in Moscow, Lenin mentioned that he had requested some unspecified acquaintance to obtain the third volume of Capital (which was published by Engels in German earlier that

\footnotetext{
2 To facilitate chronological attribution, here and thereafter in references to Lenin's works the date in square brackets indicates the year(s) of writing; the following date in brackets - the year of the first publication. All references to Lenin are based on the last Soviet editions of his collected works published in Moscow: Russian (PSS, 1960-1981) and English (LCW, 1977).

3 In January 1896, shortly after being detained in prison in St. Petersburg, Lenin wrote to his sister Anna: "[I] am busy with Tugan-Baranovsky; he has published a sound piece of research but his diagrams, those at the end, for instance, are so confused that I must confess I do not understand them; I shall have to get Volume II of Capital." (Lenin, 1896/1977). Evidently Lenin mentioned the first edition of his study of business cycles (Tugan-Baranovsky, 1894). The cited English translation in LCW by Progress Publishers is astonishingly incorrect. In the Russian original of the letter Lenin wrote about "schemes" (cf. PSS, vol. 55, p. 21). Tugan-Baranovsky's (1894) edition indeed contained 12 "diagrams" as is indicated on the cover - charts and data on cyclical fluctuations. But there are also elaborations on Marx's reproduction schemes derived from ch. XXI of the $2^{\text {nd }}$ volume. Lenin presumably referred to Scheme 2 "Accumulation of capital under the growing number of workers" (Tugan-Baranovsky, 1894 p. 411); Scheme 3 "Accumulation of capital under the constant number of workers and given techniques" (Ibid., pp. 419-420); Scheme 4 "Accumulation of capital under the progressive state of techniques” (Ibid., pp. 423-424).
} 
year) and asked her to remind this person of the request: "I should like to know because it is not easy to get that book" (Lenin, 1894/1977). ${ }^{4}$

Lenin's earliest contributions date back to 1893 , when he was $23 .{ }^{5}$ His last contributions - dictated because he was already ill and unable to write himself — were made in 1923. Several stages of Lenin's literary activity can be distinguished within those thirty years. Obviously, his primary concerns after the October revolution diverted him from theoretical issues. But at no time between the early 1890s and 1917 did he pursue any "abstract" cause. Ever since his earliest contributions he made a point of applying Marxist theory to the pertinent issues of the day and made this his main political weapon. Within the limits of this paper I shall focus on the first period of his literary activity: 1893-1899.

In the early 1890s, Lenin entered the debates between the Russian Narodniks, the socialist approach whose representatives advocated a non-capitalist path of Russia's development towards agrarian socialism, and the "orthodox Marxists," the group of young university intellectuals mainly from St. Petersburg, who argued that Russia could not circumvent the capitalist stage of development and, in fact, had already entered it, contrary to the Narodniks' claims. Lenin obviously sought to uphold the Marxist cause. But he did not initiate the debates, nor was he the major figure in them. The leading intellectuals on the Marxist side were Peter Struve, Mikhail Tugan-Baranovsky and Sergei Bulgakov. Lenin's designated enemies in that battle were the Narodniks. Yet the implicit (and interconnected) objectives of a "visiting Marxist" who arrived at the imperial capital in the fall 1893 were: to make a name for himself among the refined St. Petersburg intellectuals; to lay the foundation for political projects through establishing connections with the "circles" (groups) of radical intelligentsia and workers. The first objective was attained with "an oeuvre covering more than 1,600 printed pages" (Milios, 1999, p. 2) - the corpus of writings constituting the first three volumes of LCW. The second led to Lenin's imprisonment in December 1895 that lasted until February 1897 and subsequently to three years in Siberian exile.

The sources Lenin used for the earliest contribution comprised the works of Marx and Engels available at that period, Russian economic literature and statistical data, and a few foreign (mainly German) sources. In line with his first steps as a radical, the main reference point remained the contemporary "thick" Russian journals (PSS, vol. 1, 603-616). In May-September 1895, Lenin made his first trip abroad, visiting Austria-Hungary, Switzerland, France and Germany. He met Georgy Plekhanov, Paul Lafargue, Wilhelm Liebknecht, and other Russian and European socialists ${ }^{7}$,

\footnotetext{
4 Russian edition of the third volume would be published in 1896 by Nikolai Danielson, who was in extensive correspondence with Marx and Engels and edited also the first two volumes of Capital. During the 1890s, Danielson was the subject of Lenin's recurrent harsh criticism as a proponent of the Narodnik approach.

5 Earlier, in the late 1889 or 1890 , he translated from German the Manifesto; the manuscript of translation had some limited circulation among Lenin's acquaintances in Samara before being destroyed. (PSS, vol. 1, p. 567).

6 That is how Nadezhda Krupskaya defined Lenin recollecting his paper presentation (Lenin, 1893b/1977) at a meeting of one radical group (cited in PSS, vol. 1, p. 574, note 17). In the English edition the phrase was tactfully changed by editors into "our new Marxist friend" (LCW, vol. 1, p. 516, note 17).

7 In Geneva Lenin visited his friends from the Samara period (they got acquainted in 1890-1891): Apollon Schucht and his family, who emigrated by that time from Russia. Lenin was a godfather to their daughter Anna (1893-1963) (see Golikov et al., 1970, pp. 52, 54, 80, 101). Apollon Schucht (1860-1933) never played any significant political role. However, two sisters of Lenin's goddaughter-yet-to-be-born Yulia (1896-1980) and Tatiana (1887-1942) would play an important part in the life of Antonio Gramsci.
} 
got access to European literature and libraries, and had an opportunity to practice his language skills. ${ }^{8}$ During more than four years of imprisonment and exile Lenin obviously was restricted in access to sources, though with the help of family members he managed to get an ample supply of literature; occasionally, he was also able to work in libraries. In prison and exile he managed to start and to complete his "magnum opus" of the period - and in fact his most extensive monograph — "Development of capitalism in Russia" - based on a wide array of sources.

In January 1900, Lenin's exile ended and he left Siberia. Later that year he left Russia. The first period of his literary activity, when he laid the foundation to his claim to political leadership, was over. Except for nearly two years in 1905-1907, when he illegally stayed in St. Petersburg and then in Finland during the "First Russian revolution," Lenin's emigration in Europe lasted until 1917. Lenin fought many factional battles and continued pursuing his political project. "Bolshevism, as a distinct current in Russian Social Democracy, arose in the years 1904-1914. During those years Bolshevism was a Russian answer to Russian problems" (Lih, 2011, 84). Only after the outbreak of WWI, in 1915-1916, did Lenin return to the issues of capitalist development, with regard to its application on a global scale.

\section{Two scenarios for Russia's economic development}

If the "orthodox Marxists" indeed won over the Narodniks in the 1890s, then this could be because they began to control the Marxist narrative in Russia. In doing so, they almost erased from subsequent historiography the fact that for almost two decades before they entered the scene in the early1890s, it was up to Narodnik authors (most notably Danielson) to propagate and apply the Marxist approach in Russia. By the end of the decade, young Marxist intellectuals (Lenin included) succeeded in representing the opponents as "homegrown" (reactionary, utopian, etc.) weirdoes out of touch with "the modern theory" from the West and appropriated the monopoly over its application in Russia (almost immediately starting to struggle for that between themselves). ${ }^{9}$

The debates, however, cannot be reduced to rhetorical issues. There was the "ontological" factor behind them. One of the major paradoxes of Marx's theory consisted of a contradiction ("dialectical," as many Marxists would add) between the description of capitalism as the most productive and dynamic social system that ever existed and the forecast of its imminent breakdown due to economic reasons. This inadvertently led to interpretations of Marx's vision that conveyed either the progressive or the breakdown scenario for capitalist develop-

\footnotetext{
8 Lenin wrote to his mother from Salzburg: "This is my second day of travel abroad and I am practicing the language; I have discovered that I am weak at this and have the greatest difficulty in understanding the Germans - or rather, I don't understand them at all [...] I am not discouraged and continue distorting the German language with some zeal." (Lenin, 1895a/1977). In August, he wrote to her from Berlin: “The only bad thing is the language-I understand far less conversational German than French. The pronunciation of the Germans is so unlike what I am accustomed to that I do not even understand public speeches, although in France I understood practically everything in such speeches from the very outset." (Lenin, 1895b/1977).

9 The publications of the two alternative editions of Marx's Capital - by Peter Struve on the "liberal" side and by Ivan Skvortsov-Stepanov on the Bolshevik side — can be seen as a continuation of the fight over the right to control the Marxist narrative. Danielson's editions turned into bibliographical rarity (as well as Struve's during the Soviet period). On Russian editions of Capital see Vasina (2019).
} 
ment. At the end of the nineteenth century, Narodniks focused on the economic difficulties generated by capitalism (general impoverishment and disproportions due to the competition-driven expansion). Their opponents found themselves in rather an awkward role as the promoters of capitalist development.

Lenin met this intellectual challenge. "Recognition of the progressiveness of [capitalist development] is quite compatible [...] with the full recognition of the negative and dark sides of capitalism, with the full recognition of the profound and all-round social contradictions which are inevitably inherent in capitalism, and which reveal the historically transient character of this economic regime." (Lenin, 1899, p. 596). Hence this ushered in an assault on the Narodniks who had allegedly failed to grasp the real contradictions and problems of contemporary Russian capitalism precisely because they categorically denied its potential for growth. Skillful as it was, this rhetorical dodge could not resolve the analytical issue of combining the elements in Marx's approach that accounted for the dynamic nature of capitalism, as well as for its imminent breakdown, into a comprehensive model of Russia's economic development.

After all, it was Marx himself who (in one of the most read chapters of Capital) provided a vision of the initial stage in capitalist development - the original (primitive) accumulation - that forcefully demonstrated that the expropriation of small producers and growing misery were the preconditions for the launch into capitalist accumulation and the subsequent rise of large-scale industrial production. It was precisely what was happening in Russia, according to Narodnik economists. A conclusion from that account was that the Russian economic situation at that stage of development, "the shortage of markets," would inevitably thwart any attempt at capitalist expansion. The Narodniks highlighted Russian peculiarities, the set of institutions and factors that could allow for overcoming the capitalist impasse. But there was another, even more troubling conclusion. On the same premise, one could argue that it was the peculiarity of the situation in the major Western powers, their struggle for territorial expansion as revealed in the division of a larger part of the world by the end of the nineteenth century, which allowed them a unique leverage to counter the tendency to "general glut" inherent in any capitalist expansion.

To exorcise the ghost of a permanent "original accumulation," Lenin attempted to undermine the key thesis of the Narodnik approach: on the lack of market outlets for the products of large-scale capitalist industry engendered by its own growth:

The question of the market is entirely eliminated, because the market is nothing other than the expression of [the] division of labour and commodity production. [...] Once social economy is based on the division of labour and the commodity form of the product, technical progress must inevitably lead to the strengthening and deepening of capitalism. (Lenin, 1893b/1977, p. 108)

Furthermore, there was another important dimension in this line of criticism. Just as "the Russian road" was by no means peculiar as compared to the general trends of economic development, so too was its representation in the Narodnik economics. According to Lenin, Narodniks just reproduced formulas of the utopian petit-bourgeois reaction against the rise of capitalism as exemplified by Sismondi, but without his insights and inspiration (Lenin, 1897/1977). 
Yet, Lenin evidently was wary that the sheer demonstration of incompatibility between the premises of Marxism and the Narodnik theory of economic development was not enough. The latter argued not for the "impossibility" of capitalism, but for its "impossibility" in Russia. To reformulate in terms of the later structuralist approach, this meant the possibility of emerging the persistent duality in an economic structure of a developing nation: an outward-oriented "capitalist" sector enjoying access to foreign markets vs. an inward-oriented sector of small "commodity production" confined to the domestic or local markets. The shortageof-market thesis employed by the Narodniks' economic theory referred not only to the restrictions on selling the products of capitalist industry (the realization problem), but also to a deficient nature of the accumulation process in a backward economy (the structural problem).

Once combined in the framework of the Narodnik approach, the trend to constant disproportions between capitalist production and national income in a capitalist economy and the persistent structural heterogeneity of a developing economic system called for enhancing the potential of the "people's system" (or, to use the later term, moral economy) (cf. Lenin, 1893b/1977, p. 91) instead of pump-priming large-scale industrial production. But the same combination in the framework of the Marxist approach meant the obstacle for its application to the situation of a developing (or backward) economy.

Lenin clearly perceived the issue when handling German Krasin's outline of the ch. XXI of the $2^{\text {nd }}$ volume of Capital. In his response, Lenin first tackled the realization problem. For this, he elaborated on Marx's realization schemes, with perhaps the main analytical outcome being the notorious "law" on the greater rate of growth in production of capital goods in comparison to that of consumption goods. Redressed as "the law of the priority of heavy industry" it would gain enormous significance in the context of Soviet industrialization. Lenin himself, however, did not put much emphasis on it:

The whole meaning and significance of this law of the more rapid growth of means of production lies in the one fact that the replacement of hand by machine labour - in general the technical progress that accompanies machine industry - calls for the intense development of the production of coal and iron, those "real means of production as means of production." (Lenin, 1893b/1977, p. 105)

Thus, the "law" just represented the labor-saving character of technical progress under capitalism. As such it explained both the general (or, rather, secular) trend to impoverishment in the course of capitalist development and the counterbalancing effect of the growth of the markets for capital goods that accounted for the capitalist dynamics (interrupted from time to time by crises due to the disproportionate growth of individual sectors) in the shorter run. This, in turn, was but an analytical expression for the basic contradiction of capitalism.

This elaboration was evidence of Lenin's grasp of what he perceived to be true Marxism, derived from his intense studies of Marx since 1888 and fiercely defended thereafter. But in the context of the Russian debates of the 1890s it was not particularly original (being undoubtedly stimulated by recent publication of the $2^{\text {nd }}$ volume of Capital ). After all, Lenin's was a re-elaboration of what he perceived as 
an erroneous elaboration presented by Krasin. Lenin closely followed Marx, even though there is room for debate on the correctness of his interpretation. ${ }^{10}$

The major point of Lenin's attention was directed to the structural problem. His general conclusion was that the realization problem could be omitted from the analysis: "The limits of the development of the market, in capitalist society, are set by the limits of the specialization of social labor. But this specialization, by its very nature is as infinite as technical developments" (Lenin, 1893b/1977, p. 100). However, "the explanation of how capitalism develops in general does not in the least help to clear up the question of the 'possibility' (and necessity) of the development of capitalism in Russia" (Lenin, 1893b/1977, p. 89). "The miserable remnants of the natural economy of indigent peasants" indeed posed the methodological problem for application of Marxist theory, based on assumption of "general and exclusive domination of capitalist production" (Lenin, 1893 b/1977, p. 79). Krasin's outline evidently made Lenin aware that attempts to interpret Marxist theory in the framework of a backward economic system could hit a breach in the fortress of orthodoxy.

It seems that in Krasin the ghost of the "original accumulation" was let into the process of capitalist accumulation proper. ${ }^{11}$ At any rate, he obviously reacted to the Narodnik approach to economic development and, in Lenin's view, made an inexcusable concession to it. Krasin proposed to distinguish

two essentially different features in the accumulation of capital: 1) the development of capitalist production in breadth, when it takes hold of already existing fields of labour, ousting natural economy and expanding at the latter's expense; and 2) the development of capitalist production in depth, $[\ldots]$ when it expands independently of natural economy, i.e., under the general and exclusive domination of the capitalist mode of production. (Lenin, 1893b/1977, p. 89).

Krasin seemed to admit that the shortage-of-markets thesis was relevant for the first stage, when non-capitalist, external sectors were used as outlets for outward capitalist expansion, while criticizing "the current view" for its neglect of the stage of inward development, when the accumulated potential of the capitalist industry allowed for the growth on its own basis, "independently of any countries with direct producers, i.e., independently of so-called foreign markets" (Lenin, 1893b/1977, p. 91). Lenin unequivocally identified "the current view" with the Narodnik approach. In Krasin's own words, "if we adhere consistently to the view under examination, then we must conclude that it is not possible for the development of the capitalist mode of production to become universal". If so, capitalist development did require a sort of big push or "implementation" to expand the sphere of capitalist accumulation outside the enclaves relying "upon consumption in 'foreign' markets” (Lenin, 1893b/1977, pp. 91-92, 107-108).

\footnotetext{
10 Cf., e.g., Zarembka (2003). The claim to keeping the orthodoxy on the analytical level though, was a political asset. For example, it would allow Lenin to assume the self-imposed part of a referee in a theoretical discord between two of the most authoritative representatives of the Russian Marxism of the 1890s (Lenin, 1899/1977).

11 This hypothesis cannot be proved factually though, as the only available insight into Krasin's outline is provided by selective quotations of Lenin. Another eyewitness who left the written evidence of reading Krasin's manuscript with Lenin's notes on it, Krupskaya, mostly confined herself to a comparison of both authors' handwriting (unfavorable to Krasin). The text itself was most likely lost, see Krupskaya (1933, pp. 11-12).
} 
Krasin put "foreign" in inverted commas because the term meant not only external to the confines of a national economy, but also external to the capitalist sector within a national economy. This was a widely perceived usage of the term in the Russian debates on markets, which indicates that at that time the notion of heterogeneity of the national economic system implicitly was present in the debates, even if it was somewhat blurred with the matter of international economic relations. In the framework of the 1890 s debates, both external outlets (the noncapitalist domestic sectors and the foreign markets) were regarded as reservoirs for the capital accumulation by the national large-scale industry. Lenin criticized that view. He pointed out that there was no heterogeneity of markets:

nobody in our literature has yet prophesied the ruin of our handicraft industry because of the disappearance of "markets," although the handicraft industry produces values totalling over a thousand million rubles and supplies the very same impoverished "people.” (Lenin, 1893b/1977, p. 102)

In this sense, there were no "foreign" markets within the country once the commodity production started to unleash its transformative power. But the same logic suggested that there were no "foreign" markets for the capitalist system on the global scale:

The capitalist enterprise [...] inevitably outgrows the bounds of the village community, the local market, the region, and then the state. Since the isolation and seclusion of the states have already been broken down by commodity circulation, the natural trend of every capitalist industry brings it to the necessity of "seeking a foreign market." [...] This necessity demonstrates the progressive historical work of capitalism, which destroys the age-old isolation and seclusion of systems of economy (and, consequently, the narrowness of intellectual and political life), and which links all countries of the world into a single economic whole. (Lenin, 1898/1977, p. 66-67).

On the other hand,

the "home market" for capitalism is created by developing capitalism itself, which deepens the social division of labour and resolves the direct producers into capitalists and workers. The degree of the development of the home market is the degree of development of capitalism in the country. (Lenin, 1898/1977, p. 69)

The "notorious question of markets," thus, seemed to be closed. Lenin rejected the idea of the heterogeneous economic structure, with the non-capitalist sectors serving as the source of surplus value indispensable or accumulation in the capitalist sector. He repudiated Krasin for his readiness ("if only in part") to allow that

capitalism did indeed (?), in its infancy, develop in this very easy (sic!?) way (very easy because here existing branches of labour are involved) and is partly developing in the same direction even now (??), since there are still remnants of natural economy in the world, and since the population is growing. (Lenin, 1893b/1977, p. 92; notes in brackets are Lenin's) 
Instead, Lenin advanced the universal scheme of economic development, with the stage of achieved technical level as the decisive factor (having in mind the endogenous nature of technical progress):

it is wrong to divide the development or capitalism into development in breadth and in depth; the entire development proceeds on account of division of labour; there is no "essential" difference between the two features. Actually, however, the difference between them boils down to different stages of technical progress. In the lower stages of the development of capitalist technique - simple co-operation and manufacture - the production of means of production as means of production does not yet exist: it emerges and attains enormous development only at the higher stage-large-scale machine industry. (Lenin, 1893b/1977, p. 105 fn.)

This was, according to Lenin, the truly Marxist approach to economic development as confirmed both by Marx's theory and the "facts of life" related to the development of capitalism in Russia. However, precisely those "facts of life" soon induced Lenin to transform it. In 1893, he rejected Krasin's division between the inward ("in depth") and outward ("in breadth") capitalist development. Just a few years later, in the "Development of capitalism in Russia" (written in prison and exile in 1896-1899), he surprisingly re-introduced it:

the process of the formation of a market for capitalism has two aspects, namely, the development of capitalism in depth, i.e., the further growth of capitalist agriculture and industry in the given, definite and enclosed territory - and the development of capitalism in breadth, i.e., the extension of the sphere of the capitalist domination to new territory. (Lenin, 1899/1977, pp. 594-595).

Krasin made the distinction in terms of the dual economy. Lenin saw in it the misleading indication regarding the boundary between the sectors of precapitalist and capitalist economy that could eventually prevent the expansion of capitalist production from its original enclaves due to diminishing opportunities to extract profits from "foreign" markets (both the international and the "home market") impoverished by the destruction of the natural economy. Instead, Lenin argued, the natural economy was the cradle for the growth of capitalism. Rather than being somehow "implemented" into the natural economy in the form of enclaves, capitalism was engendered by the commodity production transforming the natural economy from within, much like a virus.

However, a closer look at the "fact of life" evidently induced Lenin to move further and to allow the structural problem in, only that the resurged distinction between the principles of inward and outward development got another meaning. Now it indicated not the structural heterogeneity within the boundaries of one economic system but rather the heterogeneity caused by colonialism, forceful imposition of capitalism over the pre-capitalist economic system. ${ }^{12}$ Lenin was keen to emphasize that it was not simply the question of territorial expansion and hastened to distinguish the politi-

\footnotetext{
${ }^{12}$ Characteristically, the distinction was introduced in the chapter "The significance of the border regions. Home or foreign market?"
} 
cal conquest and the economic "conquest." (Lenin, 1899/1977, p. 593). Nevertheless, this way - through the addition of colonialism into the original scheme of economic development — the structural problem paved its way into Lenin's reasoning:

The development of capitalism in depth in the old, long-inhabited territories is retarded because of the colonization of the outer regions. The solution of the contradictions inherent in, and produced by, capitalism is temporarily postponed because of the fact that capitalism can easily develop in breadth. [...] If Russian capitalism had possessed no range for expansion beyond the bounds of the territory already occupied at the beginning of the postReform period, [the] contradiction between capitalist large-scale industry and the archaic institutions in rural life [...] would have had to lead quickly to the complete abolition of these institutions, to the complete clearing of the path for agricultural capitalism in Russia. [...] It goes without saying that such a deceleration of the growth of capitalism is equivalent to preparing its even greater extension in the near future. (Lenin, 1899/1977, p. 595 fn.)

Without abandoning the original stance on the realization problem, Lenin admitted (albeit implicitly and with reservations) that the "market" was not simply a function of the division of labor and that the availability of "foreign markets" could influence the pace of economic development. However, to prove that this should not be the obstacle preventing capitalist expansion, Lenin explained how capitalist enterprises strive to move outside the confines of the "home market" by the same disproportions in growth between economic sectors that caused economic crises: "With the unevenness of development inherent in capitalism, one branch of production outstrips the others and strives to transcend the bounds of the old field of economic relations" (Lenin, 1899/1977, p. 591).

Thus, the notion of unevenness came to represent the dynamic dimension of the structural disproportions. Rather than exogenously set structural heterogeneity, unevenness was both the result of capitalist development conforming to the theoretical framework of Marxism and a plausible economic explanation to "facts of life" indicating a persistent divergence in the levels of development across sectors and regions on national and international levels.

"Lenin did not make a single practical decision in his whole life which was not the rational and logical outcome of his theoretical standpoint" (Lukács, 1924/2009, p. 41). Already at the earliest stage of his activity as a public intellectual Lenin demonstrated commitment to providing the firm theoretical foundations for his political activity. He was not original in his approach to application of Marx's theory to the issues of economic development among other "orthodox Marxists" of the 1890s. Nor did he make the most advanced analytical contributions in the field (suffice it to refer here to Tugan-Baranovsky's theory of business cycles). Yet, Lenin succeeded in elaborating his own line that deserves consideration in terms of intellectual history not only because it was Lenin's, but on its own merits.

At a first glance, Lenin himself did a lot to preclude any serious attention to his economic analysis. As other "orthodox Marxists," Lenin tackled the "notorious question of markets." But it is striking that in doing so it was as if Lenin avoided big issues and big names of the time. While his fellows in application of "the modern theory" to Russia adopted the latest trends, exploring Kantian philosophy, the mar- 
ginalist critique of Marxism and so on, Lenin dug into zemstvo statistics and delivered lengthy, cameralist-style explorations on that. Instead of focusing his critique, for instance, on Böhm-Bawerk, he pounced on Sismondi. ${ }^{13}$ It is hardly an exaggeration to suppose that if not for Lenin's close attention, the names of Vladimir Postnikov (Lenin, 1893a/1977), German Krasin (Lenin, 1893b/1977), Boris Ephrussi (Lenin, 1897/1977) would have been absent in the histories of economic thought. ${ }^{14}$

But behind this there was a tenacious persistence in achieving goals and an impressive ability to focus on the problem. Lenin possessed the theory (or was possessed by it). Lenin's theorizing was always built around the fights with specific designated enemies; it was just that the concrete enemies changed over the years. He hardly found it necessary to waste time and effort on clashes with representatives of the "vulgar bourgeois political economy." His true enemies were always inside Marxism and the socialist movement. At that early stage, Lenin's target was to crush the opponents of what he believed to be his rightful interpretation of Marxism in Russia. In Postnikov he found the interpretation of agricultural statistics that ran contrary to the mainstream and allowed to set the methodological foundations for his own empirical critique of the Narodnik economics; in Krasin he drew on the warning to fellow Marxists of the danger of wrongfully interpreting Marx's theory; in Ephrussi he discovered the opportunity to transform a "Romanticist" study of the history of economic thought into the theoretical critique of the Narodnik economics.

Through his criticism of opponents, Lenin made his own positive contribution to the development studies. He rejected the existence of economic obstacles to the expansion of capitalist production. Fighting Narodniks, he insisted that political and institutional "peculiarities" were but temporary impediments to the spread of the virus of commodity production. There is no place for a modernization theory in Lenin. He conceived "industrialization as a transition from one (the underdeveloped) capitalist form to another (the developed). In contrast, most contemporary approaches conceive the initial stages of industrialization as a transition from pre-capitalism to capitalism" (Milios, 1999, p. 17).

Such an approach is open to criticism as an institutionally blind one. "Like other Marxists before him, Lenin believed that peasants were a transient social element, soon to disappear before the onslaught of commercial capitalism" (Kingston-Mann, 1983, p. 3). This may lead to the claim that Lenin "ignored" the Russia peasant commune, the obshchina, and to the reintroduction of the old claim dated back to the controversy over Marx's response to the letter from Zasulitch: "Marx was correct to have taken the Russian commune seriously, quite a bit more seriously than did Lenin in St. Petersburg in 1893" (Zarembka, 2003, p. 286). Without entering

\footnotetext{
${ }^{13}$ Lenin characteristically ignored two big articles of Ephrussi with the outline of the theories of capital and profit in Rodbertus, Marx, and the Austrian School, which undoubtedly reflected the context defined by Böhm's critique of Marx following the publication of the third volume of Capital.

14 The name of German Krasin (1871-1947) is virtually absent in spite of that. He was a younger brother to influential Bolshevik Leonid Krasin, the future Soviet Narkom of foreign affairs. Both brothers participated in a socialist group, where Lenin made his paper presentation (Lenin, 1893b/1977), but at that time the elder brother was in exile. After the Revolution (and, it seems, long before it) the younger brother quit political activity and engaged in engineering, architecture and urban planning (he was a Corresponding Member of the Soviet Academy of Architecture). For whatever reason, the editors of the vol. 1 of Lenin's "Collected works" indicated "G. B. Krasin" as the author of the outline criticized by Lenin without providing any biographical information on him. This perhaps led to a widespread confusion in attributing the outline of Marx's reproduction schemes to his famous brother L. B. Krasin as is stated, e.g., in the entry on Leonid Krasin in the authoritative "Great Russian encyclopedia", see Lukovtseva (2016).
} 
the debates about the effect that the time Marx spent on drafting his (eventually brief) response might or might not have on his own understanding of Marxism, suffice it to say here that Lenin did not ignore the obshchina. He tried to dismiss the Narodnik interpretation of its existence and its economic and social meaning.

Zarembka's claim also suggests that there is an objective and unbiased snapshot of the situation in Russian agriculture that Lenin "ignored" for whatever reason, while other authors did not. However, the "facts of life" used by Lenin were the same as those available to his opponents: sketches of peasant life in the stories of the observers, in literature, and, above all, zemstvo statistics. Regarding the latter Lenin himself hinted at the problem (Lenin, 1914/1977). Zemstvo statistics was not a solid database collected according to certain established principles. The local statisticians in Russia were often driven in their activity by the movements of soul, not by precise methodology. ${ }^{15}$ Lenin understood well that to make use of those data, some theoretical interpretation was needed. Certainly, his was an interpretation, and as such it can and should be subjected to critical analysis regarding his methods, etc. (see, e.g., Kotz and Seneta, 1990). This interpretation can be then confronted with another interpretation (which may be critical or supplementary to it). But Lenin's interpretation (as well as anyone else's) cannot be plausibly dismissed by stating that it had failed to grasp "the true" picture of Russian agriculture supposedly conveyed by a myriad of heterogeneous data. Otherwise, the long overdue critical reconsideration of the 1890 s debates among the Russian radicals boils down to a simple rewrite of the alleged result ("the Marxists won against the Narodniks"), rejecting Lenin's analysis as not conforming to Narodniks' vision.

The claim that Russian agriculture had already become capitalist was arguably the most controversial element of Lenin's development studies. But it conformed to his general message: the economic development of Russia was subject to principles of capitalist accumulation, and the presence of pre-capitalist sectors could not alter that path.

Not only Lenin virtually ignored the notion of "original (primitive) capitalist accumulation" that would make its way into the Soviet debates on industrialization. As is shown above (section 3), there are reasons to suggest that he rejected it as an analytical tool and based the analysis of development on the notion of capitalist accumulation proper. If this interpretation is correct, Lenin's approach stands in contrast with the big push strategies widespread in the post-WW2 development economics.

Considering the role of market outlets for the capitalist industry, Lenin initially rejected the realization problem and dismissed the structural problem by citing Krasin's distinction between the principles of inward and outward development. He repeated that the theoretical analysis of the impact of international markets was only an unnecessary complication that could add no new insight compared to the case of the closed economy. As his studies progressed, however, Lenin made a concession to recognizing the impact of the "foreign" market on a less abstract level. It was conceived as required by the uneven character of capitalist development, with several advanced sectors or enterprises exceeding the average of the national economy in their growth. "Uneven development of individual branches of industry is, therefore, the final cause of crises and capitalism's expansionist tendencies" (Grossman, 1932/2013, p. 31).

${ }^{15}$ On the history of the Russian agrarian studies at that period as a narrative see Kotsonis (1999). 


\section{Conclusions}

As well as many "Lenins," intellectual histories of the twentieth century convey many "Marxes," not to mention "Marxisms." Following his political project, Lenin eventually carved one of the most influential interpretations of Marx's theoretical legacy: Marxism-Leninism. ${ }^{16}$ It had its origins in the discursive practices - the rhetoric aimed at ridiculing, denigrating, and suppressing opponents - of the Russian radical intelligentsia, which Lenin did not invent. ${ }^{17}$ This was perhaps the main influence of the impact of Russian radicalism in his background, rather than the alleged propensity to acts of terror. ${ }^{18}$ Striving to produce, to propagate, to control the discourse (in his case, by means of the "written word") as the principal tool to achieve political goals made Lenin quite a "post-modern" politician.

But "the living Lenin" was also quite "modern" in his approach to theory. He himself intentionally did not invent a discourse or forge "fake news." $\mathrm{He}$ believed in the power of the theory over minds and sought to promote rational knowledge to raise the consciousness of people. That theory-Marxism-is the clue to approaching "the living Lenin," as it guided his writings, his actions, and undoubtedly his thoughts. But to approach that Lenin, a consensus is required as to what is Marxism. Too often in the Lenin studies this was the Marxism (or "the real" Marx for that matter) that should have been - the one suitable for a certain context, rather than the Marxism Lenin himself had in mind. There are two different, though by no means self-excluding, questions: Who was "the living Lenin"? and What is "the real" Marxism? They are both important. Arguably the main problem of the Lenin studies was to mix them up.

This paper assumes that to approach "the living Lenin" it is necessary to understand the theory he was guided by. The main methodological obstacle for this, as it seems, consists of the fact that Lenin himself created that theory. By the 1890s, he most probably had got the revolutionary vision but did not have any ready-made theory at hand. Instead, he had picked up some elements, which he fused and on which he elaborated in the course of his political battles. The context of the 1890s channeled his early theoretical activity applying Marx's theory of capitalist accumulation to the contemporary Russia's situation. He rejected the approach that the early (transitory) stage of capitalist development required external sources to pump-prime the accumulation process inside the capitalist sector. Lenin ascribed this approach to the Narodniks and to the "Economic romanticism" which he traced back to the early-nineteenth century. The foundations to that approach were found by him in the reaction of small proprietors endangered by the rise of large-scale capitalist industry.

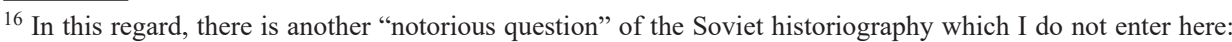
"how much Lenin was there in Stalin?"

${ }^{17}$ Marx was not immune to that practice either. Russian landlord and author Pavel Annenkov, who met Marx in 1846 , was appalled by the mode of debates led by him, which was quite opposite to the gentlemanly rules of debates adopted among the Russian intellectuals of his circle then (cf. Tvardovskaya and Itenberg, 2009, pp. 12-14).

${ }^{18}$ In fact, in the pre-revolutionary period, Lenin rejected terrorism as a futile political tool. Terrorist activity was associated more with some groups within the Socialist Revolutionaries (the Esers), the political wing of the Narodniks. Bolsheviks indeed implemented "the state of terror" soon after the takeover. But the search for their theoretical inspirations in that regard arguably should start with the interpretation of Marx's "Civil War in France" that framed their reading of the histories of French revolutions.
} 
At the same time, Narodnik economists found some validation for their arguments on the lack of resources for capitalist accumulation in Russia via Marx's depiction of the effects of capitalist accumulation in Britain and elsewhere. Furthermore, Lenin evidently perceived that Marx's outline of the original (primitive) accumulation was not incompatible with the claim of peculiarity of the development principles at a distinctive transitory stage between the state of economic backwardness and the launch to modern ("capitalist") economic growth. Lenin instead insisted on the universality of the development pattern "natural economy-commodity production - capitalist production." As I tried to show above, to provide an analytical substantiation to this thesis Lenin implicitly distinguished the realization problem - the availability of market outlets affecting the pace and the very possibility of the steady growth of the capitalist sector; and the structural problem - the possibility for the heterogeneity in the internal economic system and the situation on the global market to alter the development path of a backward economy. Initially, he rejected both. In the course of his studies, presumably under the influence of empirical data, Lenin, while maintaining the initial stance on the first, made some concession to the second. But in Lenin the unevenness - coexistence of heterogeneous economic sectors and regions on the national and international levels - was not the original (primitive) obstacle to be overcome in the course of subsequent capitalist development. Primarily, it was the effect of capitalist development.

The earliest period of Lenin's intellectual activity is remarkable as it was focused almost entirely on matters of economic theory. Lenin obviously never lost sight of the economic part of Marxist doctrine. But it was not until 1915-1916 that he once again focused his attention on those matters - and, again, in the field of economic development. In his studies of imperialism, Lenin extended (with some transformation) the framework he set up for the case of Russia to the case of the global economy.

In 1893-1899, Lenin followed the dynamic scenario of capitalist development assuming limitless economic potential for the expansion of the capitalist sector in Russia. In 1915-16, he explored the breakdown scenario for the new, "ultimate" stage in capitalist development on the global scale. In both periods of his development studies, Lenin admitted only the political breakdown of capitalism and called for catching each and every social expression of economic contradictions inherent to capitalism to smash its state apparatus. Through his personal influence and through the influence of Komintern after the Bolshevik victory, then, after WW2, by means of "hard" and "soft" Soviet power it was the mainstream of the "world Left" approach to development issues at least until 1956-1968.

\section{References}

Golikov, G. N. et al. (Eds.) (1970). Vladimir Ilyich Lenin: Biographical chronicle, 1870-1924 (vol. 1). Moscow: Politizdat (in Russian).

Gooding, J. (2002). Socialism in Russia: Lenin and his legacy, 1890-1991. Basingstoke and New York: Palgrave Macmillan.

Grossman, H. (2013 [1932]). Fifty years of struggle over Marxism, 1883-1932. In R. Kuhn. Marxist crisis theory to 1932 and to the present: Reflections on Henryk Grossman's "Fifty years of struggle over Marxism" (Appendix). Presented at the Society of Heterodox Economists Conference, University of New South Wales, Sydney, 2-3 December. Available at: https://openresearchrepository.anu.edu.au/bitstream/1885/11086/2/Grossman_FiftyYearsMarxism2013.pdf 
Kingston-Mann, E. (1983). Lenin and the problem of Marxist peasant revolution. New York and Oxford: Oxford University Press.

Kotsonis, Y. (1999). Making peasants backward: Agricultural cooperatives and the agrarian question in Russia, 1861-1914. Basingstoke and New York: Palgrave Macmillan.

Kotz, S., \& Seneta, E. (1990). Lenin as a statistician: A non-Soviet view. Journal of the Royal Statistical Society. Series A (Statistics in Society), 153(1), 73-94. https://doi. org $/ 10.2307 / 2983097$

Krupskaya, N. K. (1933). Memories of Lenin. Moscow: Partizdat (in Russian).

LCW (1977). V. I. Lenin, Collected works ( $4^{\text {th }}$ ed., 45 vols). Moscow: Progress Publishers.

Lenin, V. I. (1977 [1893a]). New economic developments in peasant life (on V. Y. Postnikov's "Peasant Farming in South Russia"). In V. I. Lenin, Collected works (vol. 1, pp. 11-73). Moscow: Progress Publishers.

Lenin, V. I. (1977 [1893b]). On the so-called market question. In V. I. Lenin, Collected works (vol. 1, pp. 75-128). Moscow: Progress Publishers.

Lenin, V. I. (1977 [1894]). To his sister Maria. December 13. In V. I. Lenin, Collected works (vol. 37, p. 68-69). Moscow: Progress Publishers.

Lenin, V. I. (1977 [1895a]). To his mother. May 14. In V. I. Lenin, Collected works (vol. 37, p. 72). Moscow: Progress Publishers.

Lenin, V. I. (1977 [1895b]). To his mother. August 10. In V. I. Lenin, Collected works (vol. 37, p. 77). Moscow: Progress Publishers.

Lenin, V. I. (1977 [1896]). To his sister Anna. January 16. In V. I. Lenin, Collected works (vol. 37, pp. 89-90). Moscow: Progress Publishers.

Lenin, V. I. (1977 [1897]). A characterisation of economic romanticism (Sismondi and our native Sismondists). In V. I. Lenin, Collected works (vol. 2, pp. 129-265). Moscow: Progress Publishers.

Lenin, V. I. (1977 [1898]). A Note on the question of the market theory (Apropos of the polemic of Messrs. Tugan-Baranovsky and Bulgakov). In V. I. Lenin, Collected works (vol. 4, pp. 55-64). Moscow: Progress Publishers.

Lenin, V. I. (1977 [1899]). The development of capitalism in Russia. In V. I. Lenin, Collected works (vol. 3, pp. 21-608). Moscow: Progress Publishers.

Lenin, V. I. (1977 [1914]). The purpose of zemstvo statistics. In V. I. Lenin, Collected works (vol. 20, pp. 82-88). Moscow: Progress Publishers.

Lewin, M. (2005 [1968]). Lenin's last struggle. Ann Arbor: University of Michigan Press.

Lih, L. T. (2011). Lenin. London: Reaktion Books.

Lukács, G. (2009 [1924]). Lenin: A study on the unity of his thought. London and New York: Verso.

Lukovtseva, T. A. (2016). Krasin. In Great Russian encyclopedia (in Russian). Available at: https:// bigenc.ru/domestic_history/text/2106355

Milios, J. (1999). Preindustrial capitalist forms: Lenin's contribution to a Marxist theory of economic development. Rethinking Marxism, 11(4), 38-56. https://doi.org/10.1080/08935699908685607

PSS (1960-1981). Lenin V. I. Complete works ( ${ }^{\text {th }}$ ed., 55 vols.). Moscow: Izdatelstvo Politicheskoy Literaturi (in Russian).

Theen, R. H. W. (1973). Lenin: Genesis and development of a revolutionary. Princeton: Princeton University Press.

Tugan-Baranovsky, M. I. (1894). Industrial crises in England. St. Petersburg: Tip. N. I. Skorokhodova (in Russian).

Tvardovskaya, V. A., \& Itenberg, B. S. (2009). Russians and Karl Marx: Choice or fate? Moscow: URSS (in Russian).

Vasina, L. (2019). Marx's "Capital” in Russia in historical retrospect (1867-2017). In L. Vasina (Ed.), The legacy of Marx: A view from the 21st century (pp. 25-55). Moscow: GPIB (in Russian).

Wada, H. (1983). Marx and Revolutionary Russia. In T. Shanin (Ed.), Late Marx and the Russian Road: Marx and the "Peripheries of capitalism." New York: Monthly Review Press.

Zarembka, P. (2003). Lenin as economist of production: A Ricardian step backwards. Science \& Society, 67(3), 276-302. https://doi.org/10.1521/siso.67.3.276.21240 